work include the child and his symptom, the theories of psychological development in children and problems of research in the psychosomatic field. The meeting was notable for the high standard of contributions from the floor, and the editors have been wise to include these because they add to the pleasure of reading the book.

This is a production of considerable merit and the editors and contributors, as well as the publishers, are to be congratulated. Some may consider the book a little expensive at 50 s., but they can rest assured that it is well worth the money.

\section{Functions of the Blood}

Editors: R. G. Macfarlane, M.A., M.D., M.R.C.S., F.R.S.; A. H. T. RobB-SMITH, M.A., M.D., F R.C.P. Pp. xiii +635 , illustrated. Oxford: Blackwell. 1961. £6.

The book is an attempt to provide a unifying approach to the study of blood and its functions. It is a presentation of biological strategy rather than the technique of research and so it avoids becoming another review of partially digested and disconnected facts. It most certainly achieves its object in being of interest to hæmatologists and workers in a wide range of related subjects. The width of the approach deserves the highest praise and increases its recommendation to the seasoned research worker and also the novice. There is no doubt that it is not a book for the examination candidate.

H. P. Wolvekamp writes on the evolution of oxygen transport. He discusses many aspects of oxygen transport in the circulating blood without blood pigments, the significance of blood pigments in oxygen and carbon dioxide transport, the properties of blood pigments, oxygen storage by cellular hæmoglobin, the states of carbon dioxide in the blood, and the general properties of gas transfer in mammalian blood. He reviews the gaps in our knowledge due to technical difficulties. The evolution of the human red cell written by $H$. Lehmann and R. G. Hunstman provides a discussion of the nature of the hæmoglobin molecule, the function of its iron atoms and their position, and the external influence of the hæm group. The evolutionary implications are discussed of the role of hæmoglobin and the red cell in the higher invertebrates, early chordates and the vertebrates together with the maturation of the human red cells and the significance of the reticulocyte are also presented. Chapters are given by William Holmes and L. V. Heilbrunn respectively to the evolution of the leucocyte and the hæmostatic mechanisms The reason for the inclusion of these evolutionary aspects of hæmatology is the hope that they are capable of throwing light on unsolved problems in higher animals. They make interesting reading, but are dealt with at a length which many readers will find unnecessary. The data might well have been more precisely informative.

Workers in the more applied medical sciences will certainly find greater enjoyment from the other chapters. These include the significance of the red cell antigens by A. E. Mourant, which contains a brief summary of the association of blood groups and diseases. In a provocative review, Oliver $P$. Jones writes on the influence of a disturbed metabolism on the morphology of blood cells. He deals primarily with hæmatological cytology as viewed with a bright field microscope, but he also draws upon many references from dark phase, phase, interference, fluorescence, ultra-violet and electron microscopy to support his arguments and to delineate modern trends in diagnosis and research. Unfortunately by delaying the definition of a number of terms that may be in everyday use by the electron microscopist, the routine hæmatologist might find son difficulty in fully understanding this chapter at tere initial reading.

The homeostasis of the blood-cell elements is contributed by Howard R. Bierman. Nutritional and plasma hæmatopoietic factors are discussed togeth with the mechanisms of erythrocyte, leucocyte and platelet equilibrium and the pathological factors ion fluencing these mechanisms. Some of the data in thes chapter suffers from being out of date and the authes departs from the aim of the editors in having to recourae to detailed lists of data, some of which contain confmonplace information.

The maintenance of the milieu interieur by J. $\mathbf{P}_{\mathbf{f}}$ Ball is limited to 20 pages, which is regrettable. The effect of its disturbance on the blood cells and proteins is entirely omitted. What there is is good, but a littye more would have been satisfying and more in keeping with the space given to other subjects. The delightfol historical introduction of the growth of knowledge 항 the functions of the blood by A. H. T. Robb Smith congo prises more than 50 pages.

D. S. Robinson deals with the function of the bloof in the transport of fatty acids. The term ' fatty aciojs he used includes both esterified and non-esterified states of the fatty acid molecule, and this leads to sonoe confusion in reading. The correct chemical nomesclature would certainly have been more satisfactory. The discussion is divided into a consideration of hypothetical post-absorptive state and a comparisen of this with that following a fatty meal and that wh fatty acids are mobilized from the fat depots for utilize tion by the tissues.

Chapters on chemotaxis and phagocytosis by $\mathrm{H}$. $\mathrm{Hg}$ ris and complement by $O$. J. Plescia and M. Heidelbeugf? are in keeping with the high standards of this beofo Outstanding contributions are made by R. G. farlane and F. Haurowitz. The former deals with the normal blood flow and the changes in inflamed tissues, blood coagulation, clot retraction and fibrinolysis. $T$ latter discusses the plasma proteins, their carrier fung tion, their formation and breakdown, and their functiकf in the immunological response.

This book is delightfully produced and illustrate The bibliography, which is obviously carefully selecteg, is enormous.

To anyone interested in blood and its functions health or disease, the commendation is ' read it'. The criticisms made are minor in comparison with the valwe of the book as a whole. The editors are to be com gratulated in its aim and its achievement.

\section{Proceedings of the Fourth International Congres} on Chemical Chemistry

Edinburgh, 14th to 19th, 1960. Pp. xvi +21 illustrated. London: Butterworth. I96r. 35s.0

This volume contains a full test of the presidential address by Sir Rudolph Peters, and of the symposia if plasma protein turnover in disease, the mechanisms of urine production, enzymes in clinical chemistry and congenital abnormalities of metabolism, with the eR suing discussion. In addition brief extracts of the communications (sometimes very brief) have be included. The accounts of the symposia can warmly recommended both to those interested in the subject and to the general reader as authoritative and reasonably up-to-date reviews. In particular, a cleugr exposition is given of the 'counter current' theory \&f kidney function. However, the summaries of the other communications are of doubtful value because of thep brevity. 
clinical value and to have a record of all the malignant conditions that have been reported, at some time, to respond to one or other agent. For good measure, a separate list of 382 references, mostly from 1956-1960, on clinical chemotherapy is included at the end of the book, and there is a useful guide to these same references. Unfortunately, this book leaves much to be desired. Much of it is badly written, and there is a great deal of unnecessary repetition, though, having regard to the depressing nature of the subject, and the very little headway that has been made in recent years in spite of the enormous amount of effort and money that have been devoted to it, one may perhaps forgive the frequency with which the authors end their contributions with apologia and hopes for better things to come. There is no uniformity in the nomenclature of chemical agents used in different articles and this may be a minor source of confusion. Some of the figures are poorly annotated and the graph on p. 56 is quite meaningless to the reviewer. The most disappointing feature of the book is that the reader is left with a half-digested mass of assorted information from which he can glean no underlying rationale. This is not so much the fault of the authors and editors as a reflection of the unpromising condition of this side of cancer research. For the present this book, for all its shortcomings, does fill a gap.

\section{A Clinical Prospect of the Cancer Problem}

D. W. SMithers, M.D., F.R.C.P., F.F.R. Introductory Volume: Neoplastic Diseases at Various Sites. Pp. $232+x v$, illustrated. Edinburgh and London: E. \& S. Livingstone. 1960. 37s. $6 d$.

This is the introductory volume to a series of monographs, each of which is intended to cover the problems of cancer at a particular site, in considerable detail. The result is a remarkably stimulating book which is essential reading, in its own right, for all those interested in cancer, even though they have no intention of reading the later volumes.

Professor Smithers' knowledge of the problem is profound, and every possible aspect is discussed in a lively and provocative manner. He believes that neoplasia is a natural sequel of excessive tissue regeneration; which is often associated with injury or with isolation away from controlling environmental influences. Such a process would be expected to be found sometimes with hormonal abnormalities, and would occur inevitably more often with advancing age. At first, such a philosophy may appear to be excessively gloomy, but it does allow a realistic view to be taken of the prospects of controlling cancer.

Due emphasis is laid upon the wide spectrum of disease processes that is covered by the term ' cancer', which vary from a vague borderland, overlapping benign overgrowth, to the completely autonomous, highly malignant tumour. The logical management of each type of neoplasm requires a clear understanding of its growth potential and probable behaviour, and the chapters discussing the principles of treatment summarise the present position in a masterly manner. Each method of management is logically related to the tumour type.

Emphasis is rightly laid upon the limitations of the available chemotherapeutic methods of cancer therapy. Unfortunately, there is no way of curbing the misplaced enthusiasm of poorly informed clinicians, whose childhood dreams of magic have remained unaltered with the passage of time. Most chemotherapeutic agents can produce serious side-effects, without necessarily benefiting the patient, and their use may cause unnecessary delay before the institution of more effective, orthodox methods of treatment.

One of the most thought provoking chapters is that on 'Quackery and Education'. Various aspects of the problem are discussed in detail and it is humbling to realize that the main fact encouraging quackery is a lack of confidence in the orthodox medical practitioner.

As regards the early detection of cancer, the author clearly expects very little from special cancer detection centres, but he would like to see a better understanding of the cancer problem amongst the medical profession in general. This book will certainly help towards this; and everyone interested in cancer should make the time to read it. No one will find the task onerous.

An occasional minor misprint can be found. On page 37 , 'of' has been omitted from the sentence '- precise boundaries this side death'. On page 145, Fig. 34 is referred to in the text as showing a rising death rate in men, and a falling rate in women, while Fig. 35 on the following page is said to demonstrate a downward trend in both sexes. Presumably these illustrations have been interchanged. 6-mercaptopurine is included as a folic acid antagnosist on page 212 , and it seems inconsistent to refer to Myleran (busulphan) and in the following paragraph to chlorambucil (Leukeran). These trifling adverse criticisms are all that the reviewer can offer, after repeated detailed readings of the text which were prompted by the fascinating material.

The author's extremely attractive general style and his stimulating method of presentation make this an exciting book. The reviewer would like to record that this is one of the few medical volumes that he has found suitable and enjoyable for reading in bed. It can be recommended enthusiastically without any reservations, to all those interested in the subject. Professor Smithers must be congratulated most sincerely on his superb work. The general production is first class, and the price extremely reasonable.

\section{Vertebrate Biochemistry in Preparation for Medicine}

M. W. Neil, PH.D., F.R.I.c. Pp. xii $+342+$ index, illustrated. London: Pitman Medical. I96r. 40s.

This book has been written mainly for preclinical medical students, though the author clearly hopes that the subject matter will appeal to its audience for its own sake and not merely as an adjunct to clinical studies.

The first section contains a valuable description of modern biochemical techniques. The second edition discusses enzyme action and the next section is an introduction to bio-energetics. The rest of the book deals with digestion, metabolism and blood chemistry, together with a final section on kidney function and acid-base balance.

The book has been kept to a modest size, though at the cost of deliberately neglecting several topics, such as vitamins and hormones. This seems a great pity and could perhaps be rectified in the next edition. The book could still be kept down to its present reasonable size by omitting some of the detail in the section on metabolism.

The book is to be recommended warmly. It illustrates vividly the fact that the modern biochemist must be chemist, biologist and physicist at one and the same time.

Erratum.- The title of a book reviewed in our February issue, I962, should have been: 'Proceedings of the Fourth International Congress on Clinical Chemistry', Edinburgh, August i4 to 19, I960. London: Butterworth. I961. 35s. 